\title{
HOW TO BE A SKEPTICAL THEIST AND A COMMONSENSE EPISTEMOLOGIST
}

\author{
Perry Hendricks
}

\begin{abstract}
Trent Dougherty has argued that commonsense epistemology and skeptical theism are incompatible. In this paper, I explicate Dougherty's argument, and show that (at least) one popular form of skeptical theism is compatible with commonsense epistemology.
\end{abstract}

\section{Introduction}

Trent Dougherty ${ }^{1}$ has argued that commonsense epistemology and skeptical theism are incompatible. ${ }^{2}$ In this paper, I explicate Dougherty's argument, and show that (at least) one popular form of skeptical theism is compatible with commonsense epistemology.

\section{Preliminaries and Dougherty's Argument}

Dougherty argues as follows:

(1) If commonsense epistemology is correct, then it is relatively easy to justifiedly believe that there exist instances of intense suffering which an omnipotent, omniscient being could have prevented without thereby losing some greater good or permitting some evil equally bad or worse.

(2) If it is relatively easy to justifiedly believe that there exist instances of intense suffering which an omnipotent, omniscient being could have prevented without thereby losing some greater good or permitting some evil equally bad or worse, then skeptical theism is not a plausible response to the problem of evil.

\footnotetext{
'See his "Epistemological Considerations," "Further Epistemological Considerations," and "Phenomenal Conservatism."

${ }^{2}$ More exactly, he claims that there is at least a superficial tension between commonsense epistemology and skeptical theism, and he issues a challenge to skeptical theists to remedy this tension. I use my terminology for the sake of simplicity. A referee suggests that this makes it appear that I am addressing a straw man. However, as I show below, Dougherty is, in fact, committed to the incompatibility of skeptical theism and commonsense epistemology, since, by his definitions of them, they entail contradictory propositions (i.e., (7) and (8)). See n. 5 for more on this.
} 
(3) Therefore, if commonsense epistemology is correct, then skeptical theism is not plausible. ${ }^{3}$

He states the evidential argument from evil as:

[4] There exist instances of intense suffering which an omnipotent, omniscient being could have prevented without thereby losing some greater good or permitting some evil equally bad or worse.

[5] An omnipotent, wholly good being would prevent the occurrence of any intense suffering it could, unless it could not do so without thereby losing some greater good or permitting some evil equally bad or worse.

[6] [Therefore,] there does not exist an omnipotent, omniscient, wholly good being. ${ }^{4}$

Finally, Dougherty states the skeptical theist position and commonsense epistemology as follows:

[MAINSTREAM SKEPTICAL THEISM] The only evidence for [premise (4)] is that there are instances of intense suffering for which we cannot think of some greater good which would have been lost if it were prevented or some evil equally bad or worse which would have resulted if it were prevented, and ... furthermore we have no reason to suppose that we would be able to think of such if it existed. ${ }^{5}$

[COMMONSENSE] If it seems to $\mathrm{S}$ that $\mathrm{P}$, then $\mathrm{S}$ thereby has a reason to believe P. ${ }^{6}$

So how does COMMONSENSE come into conflict with MAINSTREAM SKEPTICAL THEISM? It does so as follows: COMMONSENSE entails that $S$ can have evidence or reason ${ }^{7}$ to affirm premise (4) simply in virtue of the fact that it seems to her that there are instances of gratuitous ${ }^{8}$ evil, and this seeming justifies her in holding such a belief. So, COMMONSENSE entails the following:

\footnotetext{
3“Epistemological Considerations,” 172.

4"Epistemological Considerations," 173.

5"Epistemological Considerations," 173 (emphasis added). He gives several other examples of skeptical theism later in his paper. I choose this version only for the sake of convenience; everything I say in this paper is applicable to the other forms of skeptical theism Dougherty mentions as well. Moreover, he thinks that all skeptical theists are committed to MAINSTREAM SKEPTICAL THEISM, since, prior to his above characterization of skeptical theism, he says, "Skeptical theists in one way or another reply that . . ." ("Epistemological Considerations," 173). Hence, he thinks that all skeptical theists are committed to MAINSTREAM SKEPTICAL THEISM, and hence what I say about MAINSTREAM SKEPTICAL THEISM will apply to his other characterizations of skeptical theism.
}

'Dougherty, "Phenomenal Conservatism," 23. This principle is from Michael Huemer's phenomenal conservatism. See, e.g., Huemer, Skepticism and the Veil of Perception, and "Compassionate Phenomenal Conservatism."

"For the sake of simplicity, I will be taking "evidence" and "reason" to be synonymous.

${ }^{8} \mathrm{~A}$ gratuitous evil (or instance of suffering) is an evil that God could have prevented without losing a greater good or permitting an evil that is equally bad or worse. I will, therefore, use the term "gratuitous evil" as shorthand for the instances of intense suffering that Dougherty describes in premises (4) and (5). 
(7) Possibly, S is justified in endorsing premise (4) in virtue of the fact that it seems to her that premise (4) is true.

MAINSTREAM SKEPTICAL THEISM, on the other hand, claims that the only evidence for premise (4) is (and can be) our inability to think of a greater good for an instance of intense suffering, and hence the only justification S can have for endorsing premise (4) is her inability to think of a greater good (etc.). Hence, MAINSTREAM SKEPTICAL THEISM entails

(8) It is not possible for $S$ to be justified in endorsing premise (4) in virtue of the fact that it seems to her that premise (4) is true.

Thus, COMMONSENSE and MAINSTREAM SKEPTICAL THEISM entail contradictory propositions and are therefore incompatible. Further, it follows that, insofar as COMMONSENSE is plausible, MAINSTREAM SKEPTICAL THEISM is implausible. Hence premise (2) is true. ${ }^{9}$

\section{A Different Type of Skeptical Theism}

The proper response to Dougherty, in my view, is to concede that COMMONSENSE and MAINSTREAM SKEPTICAL THEISM are, indeed, incompatible. However, it is important to note that MAINSTREAM SKEPTICAL THEISM is not a thesis that all skeptical theists endorse. Indeed, one of the most popular versions of skeptical theism-Michael Bergmann's ${ }^{10}$ - radically differs from MAINSTREAM SKEPTICAL THEISM. We may state it as follows:

\section{BERGMANNIAN SKEPTICAL THEISM:}

ST1 We have no good reason for thinking that the possible goods we know of are representative of the possible goods there are.

ST2 We have no good reason for thinking that the possible evils we know of are representative of the possible evils there are.

ST3 We have no good reason for thinking that the entailment relations we know of between possible goods and the permission of possible evils are representative of the entailment relations there are between possible goods and the permission of possible evils.

${ }^{9}$ Dougherty brings out the tension between these two positions in a different way than I do. He says that MAINSTREAM SKEPTICAL THEISM, if right, must provide S, who believes premise (4) on the basis of COMMONSENSE, with a defeater for her COMMONSENSE justification. But he doubts that MAINSTREAM SKEPTICAL THEISM can provide such a defeater. Hence, a tension has arisen. It should be clear how my reply below equally applies to Dougherty's way of bringing about the tension. (It is worth emphasizing again that Dougherty's definitions of skeptical theism and commonsense epistemology entail propositions (7) and (8), so my approach is not unfaithful to his basic thesis.).

${ }^{10}$ See, e.g., Bergmann, "Skeptical Theism and Rowe's New Evidential Argument from Evil," "Skeptical Theism and the Problem of Evil," "Commonsense Skeptical Theism," and "Skeptical Theism, Atheism, and Total Evidence Skepticism." 
ST4 We have no good reason for thinking that the total moral value or disvalue we perceive in certain complex states of affairs accurately reflects the total moral value or disvalue they really have. ${ }^{11}$

What should be clear is that BERGMANNIAN SKEPTICAL THEISM does not make any claims about what evidence can or does justify one in endorsing premise (4). ${ }^{12}$ Rather, it only makes claims about our lack of reasons for thinking that certain values (and entailment relations) are representative. ${ }^{13}$ Indeed, as Chris Tucker has pointed out, BERGMANNIAN SKEPTICAL THEISM does not defeat all arguments from evil since there are arguments that do not make use of an inductive inference that is vulnerable to Bergmann's skeptical theses. ${ }^{14}$

However, it is important to note that Bergmann never claimed that his skeptical theses defeat all arguments from evil! Indeed, he says the following:

[Proponents of BERGMANNIAN SKEPTICAL THEISM] don't claim that their skeptical theses undermine all arguments from evil . . . [BERGMANNIAN SKEPTICAL THEISM is] used by the skeptical theist to target inductive inferences from God-justifying reasons we can think of . . . to the conclusion that there are no God-justifying reasons for permitting the evils we know of. . . . But this doesn't show that all arguments from evil rely on inductive inferences. ${ }^{15}$

Thus, the proponent of BERGMANNIAN SKEPTICAL THEISM ought to concede that not all evidential arguments from evil are undermined by her skeptical theism. Hence, she ought to reject MAINSTREAM SKEPTICAL THEISM and allow that there may be multiple ways to motivate or justify one in endorsing premise (4).

Since the affirmation of MAINSTREAM SKEPTICAL THEISM is what brought the skeptical theist into conflict with COMMONSENSE, Dougherty's challenge is met; the proponent of BERGMANNIAN SKEPTICAL THEISM is not committed to (8), and hence she is not in conflict with (7), and thus she is not in conflict with COMMONSENSE. (Indeed, we may go further and say that, in principle, one who endorses BERGMANNIAN SKEPTICAL THEISM may have reason or justification, by COMMONSENSE, to endorse premise (4). More on this later.) Therefore, one may endorse both BERGMANNIAN SKEPTICAL THEISM and COMMONSENSE; their plausibility is compossible. It follows from this that premise

\footnotetext{
${ }^{11}$ Bergmann "Commonsense Skeptical Theism," 11-12.

${ }^{12}$ Of course, the proponent of BERGMANNIAN SKEPTICAL THEISM could go beyond the skeptical theses and make claims about what kinds of evidence or justification for premise (4) there could (and could not) possibly be. My point is merely that her theses do not commit her to doing so.

${ }^{13}$ Of course, thesis (4) has other implications, but I will gloss over them here for the sake of simplicity.

${ }^{14}$ Tucker, "Why Skeptical Theism Isn't Skeptical Enough."

${ }^{15}$ Bergmann, "Skeptical Theism, Atheism, and Total Evidence Skepticism," 210 (emphasis added).
} 
(2) of Dougherty's argument is false: Skeptical theism does not entail that one cannot relatively easily justifiedly believe that there are instances of gratuitous evil-or, at least, one popular form of skeptical theism does not entail this. ${ }^{16}$ Therefore, Dougherty's conclusion is avoided: Skeptical theism - or, at least one form of it - is not incompatible with COMMONSENSE; COMMONSENSE, if plausible, does not render skeptical theism implausible. ${ }^{17}$

\section{Is BERGMANNIAN SKEPTICAL THEISM's Scope Narrow?}

One might wonder whether the compatibility of BERGMANNIAN SKEPTICAL THEISM with COMMONSENSE is a double-edged sword: While it is an advantage for BERGMANNIAN SKEPTICAL THEISM to be able to accommodate COMMONSENSE, it appears to narrow its scope and thus make it an ineffective response to many arguments from evil. In this section, I will address this issue, arguing that (a) BERGMANNIAN SKEPTICAL THEISM, even when conjoined with COMMONSENSE, still hits its original target, and hence its scope is not narrowed, and that (b) BERGMANNIAN SKEPTICAL THEISM is still, for many persons, an effective response to many arguments from evil.

In accommodating COMMONSENSE, it might be objected that the proponent of BERGMANNIAN SKEPTICAL THEISM leaves herself vulnerable many arguments from evil, such as the one contained in (4)-(6). Hence, its scope is narrowed. ${ }^{18}$ The reasoning behind this charge is twofold. In the first place, BERGMANNIAN SKEPTICAL THEISM itself does nothing to undermine either premise (4) or premise (5); BERGMANNIAN SKEPTICAL THEISM targets certain inductive inferences (explained below), none of which are mentioned in premises (4) or (5). In the second place, the compatibility of BERGMANNIAN SKEPTICAL THIESM and COMMONSENSE entails that one can have COMMONSENSE justification for arguments from evil (e.g., (4)-(6)); since BERGMANNIAN SKEPTICAL THEISM is compatible with COMMONSENSE, its proponent cannot wield it to combat arguments from evil predicated on, or justified by, COMMONSENSE. Thus, argues the objector, BERGMANNIAN SKEPTICAL THEISM's scope is narrowed; it does not address arguments from evil that do not make use of an inductive inference, nor does it address COMMONSENSE based arguments from evil. Is this objection successful?

\footnotetext{
${ }^{16}$ It is worth noting that the above defense can also be applied to Daniel Howard-Snyder's stronger "Agnostic Theses" defended in his "Epistemic Humility," as well as other forms of skeptical theism.

${ }^{17} \mathrm{~A}$ referee asks whether a person $\mathrm{S}$ would be justified by COMMONSENSE in rejecting BERGMANNIAN SKEPTICAL THEISM if it seems to her to be false. If the answer is "Yes," then, the referee says, COMMONSENSE and BERGMANNIAN SKEPTICAL THEISM are not compatible. This is incorrect. COMMONSENSE and BERGMANNIAN SKEPTICAL THEISM are compatible in the sense that one does not entail the denial of the other. That fact does not change by conceding that some persons in some situations may have COMMONSENSE justification for rejecting BERGMANNIAN SKEPTICAL THEISM.
}

${ }^{18}$ This objection is owed to a referee. 
It is true that the proponent of both BERGMANNIAN SKEPTICAL THEISM and COMMONSENSE ought to concede that, for example, if it seems to $S$ that premises (4) and (5) are true, then $S$ may justifiedly accept (6). (Note that while some allege that they have this type of justification, I doubt that premise (4) - or any proposition asserting that there is gratuitous evil-seems true to anyone. It is analogous, in my view, to a person, after witnessing a natural human birth, claiming that it seems to her that there is no possible pain more intense than giving birth. Or to a person, upon seeing Mount Everest, claiming that it seems that Mount Everest is the tallest mountain in the universe. Even if one testified to having such seemings, I would doubt the veracity of her testimony - she would appear merely to be confused; it is doubtful that she understands what she is saying. ${ }^{19}$ But I will put my incredulity aside for the moment.)

This outcome will be true for any other version of the argument from evil: so long as the premises seem to be true to $S$, she will be justified in accepting the conclusion. Or, more concretely, BERGMANNIAN SKEPTICAL THEISM permits that $S$ may, via COMMONSENSE, justifiedly conclude that God (at least probably) does not exist if an instance of evil seems gratuitous to $S$ and S holds that God's existence is incompatible with gratuitous evil.

However, the crucial issue is whether this concession actually narrows the scope of BERGMANNIAN SKEPTICAL THEISM. Does it? I submit that it does not. Recall that BERGMANNIAN SKEPTICAL THEISM targets arguments from evil that make use, implicitly or explicitly, of inductive inferences. More specifically, it targets arguments that make use of inductive inferences like the following:

THE NOSEEUM INFERENCE: ${ }^{20}$ We do not know of any morally justifying reason for God to allow instances of intense suffering; therefore, probably, there is no such reason.

BERGMANNIAN SKEPTICAL THEISM renders THE NOSEEUM INFERENCE (and other inferences like it) bad. Hence, arguments from evil that rely on it will be undermined. ${ }^{21}$ COMMONSENSE does not magically turn

\footnotetext{
${ }^{19}$ If a person really claimed that it seemed to her that Mount Everest is the tallest mountain in the universe, we ought to ask her if she just means that Mount Everest seems very tall. Presumably, this - or something like this - is what she meant by her utterance. Similarly, if a person claims that it seems to her that there are instances of suffering such that the elimination of such instances would not have resulted in a loss of a greater good or a production of an evil that is equally bad or worse, we ought to ask her if she just means that an evil seems particularly intense or bad. Presumably, this - or something like this -is what she meant by her utterance. (If she doubles down and says that she really does mean that it seems to her that there are instances of suffering such that their elimination would not have resulted in the loss of a greater good (etc.), then I would, again, doubt the veracity of her testimony or whether she understood the question.)

${ }^{20}$ This term is taken from Stephen Wykstra "Rowe's Noseeum Arguments from Evil."

${ }^{21}$ In this essay, I merely assume that BERGMANNIAN SKEPTICAL THEISM undermines THE NOSEEUM INFERENCE. This is because (a) this has been substantially argued for elsewhere (see below), and (b) my paper is concerned primarily with the compatibility of
} 
a bad inference into a good one, and hence COMMONSENSE does not narrow the scope of BERGMANNIAN SKEPTICAL THEISM.

Here it might be objected that if it seems to $S$ that THE NOSEEUM INFERENCE is a good inference, then $S$ thereby has justification for affirming it. And hence COMMONSENSE does undermine the efficacy-narrow the scope- of BERGMANNIAN SKEPTICAL THEISM.

It is, of course, possible that it seems to $S$ that THE NOSEEUM INFERENCE is good. But $S$, in such a case, would not have justification via COMMONSENSE for her belief, for she has a defeater for it. That is, the fact that BERGMANNIAN SKEPTICAL THEISM renders THE NOSEEUM INFERENCE bad is a defeater for S's seeming; it blocks-or, at least, nullifies-any justification $S$ would have via COMMONSENSE. ${ }^{22}$ (This is similar to a situation in which it seems to $S$ that a stick in the water is bent and yet she lacks justification via COMMONSENSE for her belief that it is bent, since she has an undercutting defeater for her seeming.) Hence, COMMONSENSE does not threaten to narrow the scope of BERGMANNIAN SKEPTICAL THEISM. It does not provide justification for THE NOSEEUM INFERENCE.

So, the original target of BERGMANNIAN SKEPTICAL THEISM-arguments that are, implicitly or explicitly, predicated on THE NOSEEUM INFERENCE - is still hit, and COMMONSENSE does nothing to undermine this. This, I will argue, enables BERGMANNIAN SKEPTICAL THEISM to remain an effective response to many arguments from evil for many of its proponents. The reason I use the qualification "for many" is because COMMONSENSE delivers person-relative justification: If it seems to $S$ that $p$ and it does not seem to $R$ that $p$, only $S$ will have justification for $\mathrm{p}$. The relevance of this will become clear below.

To see how BERGMANNIAN SKEPTICAL THEISM can remain an effective response for many to arguments from evil, consider the following

skeptical theism and commonsense epistemology, not with arguments in favor of skeptical theism. For defenses of the thesis that BERGMANNIAN SKEPTICAL THEISM undermines THE NOSEEUM INFERENCE, see, e.g., Bergmann "Skeptical Theism and Rowe's New Evidential Argument from Evil" and "Skeptical Theism and the Problem of Evil," Hudson "The Father of Lies?" and A Grotesque in the Garden, and my "Sceptical Theism and the Evil-God Challenge."

${ }^{22}$ Perhaps one might object that the defeater is the other way around: S's COMMONSENSE justification gives her a defeater for her belief that BERGMANNIAN SKEPTICAL THEISM undermines THE NOSEEUM INFERENCE. I do not, at this point, wish to wade into the deep waters of defeaters here, but I will briefly explain why I do not think that this objection works. BERGMANNIAN SKEPTICAL THEISM functions as an undercutting defeater for THE NOSEEUM INFERENCE: It provides $S$ with knowledge that it is a bad method of producing beliefs, and therefore it gives her reason to remain agnostic about the product of THE NOSEEUM INFERENCE (i.e., that there probably is no morally justifying reason for intense instances of suffering) - at least that is what we have assumed in this essay (see n. 21). Thus, since THE NOSEEUM INFERENCE is known to be bad, a seeming will not erase this fact, and this is a defeater for any seeming that THE NOSEEUM INFERENCE is good. Consider another example: If $S$ knows that $X$ is a bad method for producing beliefs, then the fact that it seems to her that $X$ is a good method will not provide her with justification for holding beliefs produced by X. 
scenario. Suppose that the proponent of the argument from evil as stated in (4)-(6), call her " $\mathrm{P}$," presents her interlocutor, call her " $\mathrm{L}$," with premise (4). L, we may suppose, is a proponent of BERGMANNIAN SKEPTICAL THEISM and COMMONSENSE. However, L does not have COMMONSENSE justification for premise (4) (i.e., it does not seem to her to be true). What is $\mathrm{P}$ to do here? Well, $\mathrm{P}$ must find some other way to motivate premise (4) for $\mathrm{L}-$ she must give $\mathrm{L}$ good reason to endorse premise (4). What reason could she give? One way-perhaps the only way-would be for $P$ to present $L$ with THE NOSEEUM INFERENCE. Suppose that P indeed uses THE NOSEEUM INFERENCE to argue in favor of premise (4). What is L to make of P's argument? She will not be impressed or moved by P's case for premise (4). This is because, as mentioned above, BERGMANNIAN SKEPTICAL THEISM renders THE NOSEEUM INFERENCE bad, and hence premise (4) will remain unmotivated for L. Thus, P's original argument has not gotten off the ground - she has not given L good reason to accept premise (4). ${ }^{23}$

Therefore, I conclude, BERGMANNIAN SKEPTICAL THEISM is still relevant to the argument contained in (4)-(6) - at least, it is relevant if the person entertaining it does not have justification via COMMONSENSE for premise (4).

This same problem will arise for any argument from evil that contains a premise stating either that there is gratuitous evil or that there probably is gratuitous evil. If $L$ does not have COMMONSENSE justification for the premise about gratuitous evil, then $\mathrm{P}$ will have to offer additional support for said premise. ${ }^{24}$ If the additional support amounts to THE NOSEEUM

\footnotetext{
${ }^{23}$ To make this clearer, we can consider a different scenario. Suppose, instead, that $\mathrm{P}$ owns a 500-acre strawberry field and that she prides herself on having no rotten strawberries in her field. In an attempt to convince $\mathrm{L}$ that there are no rotten strawberries in her field, $\mathrm{P}$ takes $\mathrm{L}$ to her field and they examine five acres of it. After finding no rotten strawberries, $\mathrm{P}$ asks $\mathrm{L}$ whether she now believes her. Does $\mathrm{L}$ now accept that $\mathrm{P}$ has no rotten strawberries in her field? If $\mathrm{L}$ has reason to doubt that the five acres they searched are representative of the whole garden, then she does not accept P's claim. If she has reason to doubt that the five acres are representative, then she and P not finding a rotten strawberry is scant evidence for there being none in her field. If she has reason to doubt that the contents of the 495 acres of the garden resemble the five acres that they searched through, should she regard their coming up empty-handed in their search as good reason to think that there are not rotten strawberries in the rest of the garden? The answer is simple: She should not. As it is with the strawberry garden, so it is with P's argument for premise (4): L should not accept it.

${ }^{24}$ I suspect that some arguments that do not mention gratuitous evil at all may nevertheless be vulnerable to BERGMANNIAN SKEPTICAL THEISM. For example, Paul Draper ("Pain and Pleasure"; "The Skeptical Theist" "Limitations of Pure Skeptical Theism") has argued that $\mathrm{P}(\mathrm{O} / \mathrm{HI})>! \mathrm{P}(\mathrm{O} / \mathrm{G})$, and that this gives us reason to reject $\mathrm{G}$. (Read: the probability of our observations about the patterns of pain and pleasure in our world $(\mathrm{O})$ on the hypothesis that sentient beings and nature in our world are not the product of a benevolent (or malevolent) non-human person (HI) is antecedently much greater than the probability of $\mathrm{O}$ on the hypothesis that God, an omnipotent, omniscient, and wholly good being, is the responsible for the existence of sentient beings and nature (G) ("The Skeptical Theist," 189).) However if we find $\mathrm{P}(\mathrm{O} / \mathrm{G})$ to be inscrutable, then Draper must give us reason to assign a (presumably, low) value to it; if $\mathrm{P}(\mathrm{O} / \mathrm{G})$ is truly inscrutable, then we cannot reasonably say that $\mathrm{O}$ is more likely on another proposition. One such reason might go like this: if there is no morally justifying reason for God allowing (or causing) $\mathrm{O}$, then $\mathrm{P}(\mathrm{O} / \mathrm{G})$ is low. We know of no
} 
INFERENCE (or something like it), then BERGMANNIAN SKEPTICAL THEISM comes into play, leaving the premise unmotivated for $L$ and thus undermining P's argument. Insofar as many (most? all?) persons do not have COMMONSENSE justification for believing that there is gratuitous evil, ${ }^{25}$ many arguments from evil will require additional support for their premises asserting that there is gratuitous evil. And insofar as the additional support offered amounts to THE NOSEEUM INFERENCE (or something like it), BERGMANNIAN SKEPTICAL THEISM will continue to apply to many arguments. So, I suggest that BERGMANNIAN SKEPTICAL THEISM is still an effective response to many arguments from evil for many persons; for those who lack COMMONSENSE justification for believing there is gratuitous evil, BERGMANNIAN SKEPTICAL THEISM continues to undercut many arguments from evil.

\section{Conclusion}

In this paper, we have seen that (at least) one form of skeptical theism is compatible with COMMONSENSE, and hence we ought to reject premise (2) of Dougherty's argument. I do not claim that BERGMANNIAN SKEPTICAL THEISM is the only form of skeptical theism that is compatible with COMMONSENSE - there are no doubt others. My point is merely that not all skeptical theists are committed to their incompatibility. ${ }^{26} \mathrm{~A}$ lesson from this is that we ought to talk about the implications of types of skeptical theism, rather than skeptical theism simpliciter. ${ }^{27}$

Trinity Western University

\section{References}

Bergmann, Michael. 2001. "Skeptical Theism and Rowe's New Evidential Argument from Evil." Noûs 35: 278-296. https://doi.org/10.1111/0029-4624.00297

such reason, therefore, probably, there is no such reason (i.e. THE NOSEEUM INFERENCE), and hence $\mathrm{P}(\mathrm{O} / \mathrm{G})$ is (probably) low. But, clearly enough, BERGMANNIAN SKEPTICAL THEISM will undermine this inference, leaving $\mathrm{P}(\mathrm{O} / \mathrm{G})$ inscrutable, and leaving us without motivation for thinking $\mathrm{P}(\mathrm{O} / \mathrm{HI})>$ ! $\mathrm{P}(\mathrm{O} / \mathrm{G})$, and hence without reason to reject $\mathrm{G}$. (Of course, Draper thinks there are other ways to motivate his probability claim; I will not address those arguments here. My point is merely that BERGMANNIAN SKEPTICAL THEISM may come into play when considering Draper's argument.)

${ }^{25}$ See n. 19 above and its corresponding text for the reasons I am dubious that many (if any) enjoy this type of justification.

${ }^{26}$ For other responses to Dougherty, see, e.g., Matheson "Epistemological Considerations" and "Skeptical Theism and Phenomenal Conservatism," and Rutledge, "Commonsense, Skeptical Theism, and Different Sorts of Closure of Inquiry Defeat."

${ }^{27}$ Thanks to Brett Lunn and Joshua Rosario for comments on a previous draft of this paper. And thanks especially to G.L.G. - Colin Patrick Mitchell-for particularly insightful comments. 
Bergmann, Michael. 2009. "Skeptical Theism and the Problem of Evil." In The Oxford Handbook of Philosophical Theology, edited by Thomas Flint and Michael Rea (Oxford University Press), 375-399.

Bergmann, Michael. 2012. "Commonsense Skeptical Theism." In Reason Metaphysics, and Mind: New Essays on the Philosophy of Alvin Plantinga, edited by Kelly James Clark and Michael Rea (Oxford University Press), 9-37.

https://doi.org/10.1093/acprof:oso/9780199766864.001.0001

Bergmann, Michael. 2014. "Skeptical Theism, Atheism, and Total Evidence Skepticism." In Skeptical Theism: New Essays, edited by Trent Dougherty and Justin McBrayer (Oxford University Press), 209-220.

Dougherty, Trent. 2008. “Epistemological Considerations Concerning Skeptical Theism." Faith and Philosophy 25: 172-176.

https://doi.org/10.5840/faithphil200825215

Dougherty, Trent. 2011. "Further Epistemological Considerations Concerning Skeptical Theism." Faith and Philosophy 28: 332-340.

https://doi.org/10.5840/faithphil201128331

Dougherty, Trent. 2014. "Phenomenal Conservatism, Skeptical Theism, and Probabilistic Reasoning." In Skeptical Theism: New Essays, edited by Trent Dougherty and Justin McBrayer (Oxford University Press), 21-31.

Draper, Paul. 1996a. "Pain and Pleasure: An Evidential Problem for Theists." In The Evidential Argument from Evil, edited by Daniel Howard-Snyder (Indiana University Press), 12-29.

Draper, Paul. 1996b. "The Skeptical Theist." In The Evidential Argument from Evil, edited by Daniel Howard-Snyder (Indiana University Press), 175-192.

Draper, Paul. 2013. "The Limitations of Pure Skeptical Theism" Res Philosphica 9: 97-111. https://doi.org/10.11612/resphil.2013.90.1.6

Hendricks, Perry. 2018. "Sceptical Theism and the Evil-God Challenge." Religious Studies. https://doi.org/10.1017/S0034412518000094

Howard-Snyder, Daniel. 2009. "Epistemic Humility, Arguments from Evil, and Moral Skepticism." In Oxford Studies in Philosophy of Religion: Volume 2, edited by Jonathan Kvanvig (Oxford University Press), 17-57.

Hudson, Hud. 2014. "The Father of Lies?" In Oxford Studies in Philosophy of Religion: Volume 5, edited by Jonathan Kvanvig (Oxford University Press), 147-166.

Hudson, Hud. 2017. A Grotesque in the Garden (Xerxes Press).

Huemer, Michael. 2001. Skepticism and the Veil of Perception (Rowman and Littlefield).

Huemer, Michael. 2007. "Compassionate Phenomenal Conservatism.” Philosophy and Phenomenological Research 74, 30-55.

https://doi.org/10.1111/j.1933-1592.2007.00002.x

Matheson, Jonathan. 2011. “Epistemological Considerations Concerning Skeptical Theism: A Response to Dougherty." Faith and Philosophy 28: 323-331. https://doi.org/10.5840/faithphil201128330

Matheson, Jonathan. 2014. "Skeptical Theism and Phenomenal Conservatism." In Skeptical Theism: New Essays, edited by Trent Dougherty and Justin McBrayer (Oxford University Press), 3-20. 
Rutledge, Jonathan Curtis. 2017. "Commonsense, Skeptical Theism, and Different Sorts of Closure of Inquiry Defeat." Faith and Philosophy 34: 17-32. https://doi.org/10.5840/faithphil201712576

Tucker, Chris. 2014. "Why Skeptical Theism Isn't Skeptical Enough.” In Skeptical Theism: New Essays, edited by Trent Dougherty and Justin McBrayer (Oxford University Press), 45-63.

Wykstra, Stephen. 1996. "Rowe's Noseeum Arguments from Evil." In The Evidential Argument From Evil, edited by Daniel Howard-Snyder (Indiana University Press), 126-150. 